\title{
Learning Environment in the Digital Age: Supporting the Student
}

\author{
Seppo Sirkemaa \\ Turku School of Economics and Business Administration, Pori unit, \\ Pori, Finland
}

\section{seppo.sirkemaa@pori.tukkk.fi}

\begin{abstract}
Technology can be utilized in education in several ways. Here we study development of a modern learning environment that integrates information technology into the learning process.

Modern learning environments have two main functions: they can help in using traditional and digital media in learning. In addition, learning environment provides information on the courses and studies. A learning environment is also important in managing the technology and media in the digital age. We argue that learning environme nts can become a valuable source of advice and support learning during the studies. The theoretical contribution of this article is recognition of key dimensions of the learning environment.
\end{abstract}

Keywords: information technology, learning environment.

\section{Introduction}

Information technology (IT) affects our life profoundly. IT has had a major impact on education as well. Firstly, it has highlighted the importance of continuous IT education that makes it possible to use changing technology. Secondly, IT has introduced new tools for educators and students to be used in the learning process. Consequently, there has been an explosion in both teaching and learning with new techno logy.

In this paper we discuss the importance of building a learning environment that helps in using the technology effectively in learning. Here a modern learning environment is defined as a space or environment for studying. It takes advantage of IT and integrates technology into the learning process (Vivet, 1996; Sumner, \& Taylor, 1998; Scott, \& Philips, 1998; Jonassen, 2000).

In general, modern learning environments have two main functions. Firstly, they can help in learning to use traditional and digital media in learning. Secondly, a learning environment provides information on the courses and studies (Sumner, \& Taylor, 1998). We argue that learning environments have a important role in integrating the media and technology. In addition, the environment can be a significant source of advice and support learning during the studies.

Material published as part of these proceedings, either on-line or in print, is copyrighted by Informing Science. Permission to make digital or paper copy of part or all of these works for personal or classroom use is granted without fee provided that the copies are not made or distributed for profit or commercial advantage AND that copies 1) bear this notice in full and 2) give the full citation on the first page. It is permissible to abstract these works so long as credit is given. To copy in all other cases or to republish or to post on a server or to redistribute to lists requires specific permission from the publisher at Publisher@InformingScience.org

\section{The Role of the Learning Environment}

Today technology has an important role in education. However, technology can be utilized in many ways. This continuum starts from information delivery and ends with cognitive tools (Reeves, \& Laffey, 1999). Cognitive tools refer to adaptive technology or systems that are developed 
to support and improve learning process (Jonassen, Reeves, Hong, Harvey, \& Peters, 1997; Jonassen, 2000). For example, a library system may be considered as a information delivery system whereas a software that is aimed for learning Spanish language is a cognitive tool. Both information delivery systems and cognitive tools are part of the learning environment. The learning environment is here defined as a place to study, or an environment for the learning process (Vivet, 1996; Jonassen, 2000). The attribute "modern" is used to emphasize the role of information technology in the learning process. In general, the difference with concepts learning environment and learning process is roughly the same as with words teaching, studying and learning (Tella, Vahtivuori, Vuorento, Wager, \& Oksanen, 2001).

When we look at learning from a student's perspective knowing what to do and why is a important part of the learning process. The student must get information on what must be done in order to do the course. The environment must present the structure of the course so that the student understands what exercises etc. are coming next. Therefore supporting the learning process is important (Bailey, Brown, \& Kelly, 1997).

Here we argue that modern learning environments can become a valuable source of advice and support learning during the studies. Learning environments have two main functions as they (Sumner, \& Taylor, 1998):

- Help in learning to use traditional and digital media in learning.

- Provide information on the courses and studies.

Learning environments can support learning processes and help in using the media. A modern learning environment should be a platform that makes it possible to access different kinds of material that is available in digital format. In addition, the environment should help in accessing paper-based material as well.

In traditional, paper- and lecture-based education have study guides had an important role in providing advice and guidance. However, relying on study guides is not enough in the digital age. Students have also other problems than deciding what courses to select and why. Firstly, students must cope with complex and sometimes unreliable information technology. Secondly, the information is presented in a variety of forms, both in books and journals but increasingly in files and networks. Thirdly, students need to develop new stud ying habits in order to learn effectively with the information technology. As a result, managing the media and technology in learning becomes a critical success factor.

Students have lots of questions like "what should I do next?" and "do I have to take this course?". Answers, advice and support is needed, no matter what technology is used and whether students are in the faculty or at distance. The support is important at the beginning of the student life, but also later during the studies is guidance needed. This is because each course raises que stions before, during and after the course, and they all need to be answered. The motivation is that telling students "what" and "why" can improve student's performance (Conway, \& Kahney, 1987).

The learning environment has a critical role in the learning process. It should foster meaningful learning and constructive cognitive learning processes (Jonassen, Peck, \& Wilson, 1999). Ideally, the environment activates the learner and requires critical thinking. The result is that the learner is engaged in reflective thinking, which supports knowledge construction (Jonassen, 2000).

\section{Key Elements in a Learning Environment}

A modern learning environment needs to be more than a study guide in computer format. Here we discuss the key elements in a modern learning environment that takes advantage of information technology (Table 1). 


\begin{tabular}{|l|}
\hline Characteristic \\
\hline Understand the relationship between tasks and resources \\
\hline Integration \\
\hline Establish and maintain new study habits and ways of working \\
\hline Confidence building \\
\hline Enrichment and annotation \\
\hline Tracking and feedback \\
\hline
\end{tabular}

\section{Table 1: Key elements in learning environments (Summer, \& Taylor, 1998; Scott, \& Phillips, 1998)}

Students should understand of the role of different learning tools and resources in each course. This knowledge orientates and motivates the students to use these in the most effective way. Students also need support in bridging various activities to the goals of the course. For example, written course material and exercises need to be connected together. Also hands-on advice and help are often necessary.

In traditional, class-room based education can orientation, motivation and bridging be addressed by teachers and other students in the classroom (Taylor, Sumner, \& Law, 1997). In such an environment personal advice and hands-on help are not a problem. However, in modern learning environments this is a challenging task. The overall resources can be made explicit and connected together, but hands-on help is a more complicated issue. As an extreme exa mple, in distance learning advice and tutoring are limited to the tools that the student is using, and these are often the ones that students have problems with.

The learning environment should also establish and maintain new study habits and ways of working. The students need to learn to use information as a tool in learning. The role of personal hands-on advice and tutoring are important in learning to use technology in studying. Advice and tutoring are required in the beginning of the studies, but also in the beginning of each course is support needed. Typically, younger students cope with technology easily, but for adult students can computers, and file formats become a real barrier to studying. Differences in skills using technology are large even among students with "similar" background. It is also important to maintain motivation and the methods of studying once they have been learned. Therefore each course should be planned so that student must continuously use the available technology and resources.

Confidence in the technology is important. Therefore the reliability and robustness of the learning environment are important. Technology should function smoothly without interruptions, otherwise the confidence is rapidly lost. The learning environment should also be easy to navigate and understand. Finding information, adding and modifying content needs to be straightforward for both teachers and students.

Integration refers here to integrating existing tools, resources and media into a common workplace. When all tools and resources can be found from one place it becomes faster and more efficient to access and combine information. Therefore, providing a common access-point to learning material is typical to a modern learning environment.

Enrichment and annotation are connected to adding and modifying the material and content in the learning environment. The modifications need to be possible without technical expertise or help from ITpeople. It should also be possible to adapt the environment to user's requirements. This should make it possible for both teachers and students to share their ideas and questions. 
Generally, feedback increases motivation and it is considered essential for effective learning process (Rowntree, 1992). Feedback gives student a more realistic view of skills and knowledge (Scott, \& Phillips, 1998). In traditional classroom-based education feedback can happen face-to-face and range from one-to-one conversation to a group discussion. However, in "virtual" learning there is lack of immediate feedback. Even though the richness of face-to-face discussion is lacking, technology can be used in giving feedback to student and in tracking the study progress. In addition, information technology allows customization of the learning experience and respects different learning styles (Albright, 1999; Wild, \& Quinn, 1998). Fit to individual preferences and learning style - also called adaptation - can further increase motivation and empower students to study further.

\section{Discussion}

Students need guidance and support during their studies. In the digital age students need to be skilled computer users and able to deal with different types of media in order to study effectively. It seems that studying requires skills in using technology as a tool in the learning process. But technical expertise alone is not enough - one must know what to study, where to find information, what to do next etc. Therefore special attention is needed in teaching and orientating students to use technology so that they learn to study in a modern learning environment.

Technology can be utilized in education in several ways. This continuum starts from information delivery and ends with cognitive tools, which refer to technology or systems that are developed to support and improve the learning process. Technology should adapt to students, teachers and the content of the courses. Consequently, the environment needs to be modified to fit different users and their needs. Adapting computer-based learning environments to differently skilled learners is one of the greatest challenges of the developers of the environment (Raskin, 2000, 68-70).

The modern learning environment integrates media and technology. It is a channel for feedback and sharing ideas. Furthermore, the learning environment functions as a tutor and motivates the student as the studies proceed. However, despite sophisticated technology, teaching resources and learning environment students also need to discuss their problems face-to-face. The role of a learning environment is still significant, and it can become a valuable source of information and support learning during the studies.

To summarize, the learning environment should support the learning process in the best possible way. Here understanding the key elements in a learning environment is critical. We suggest that the developers of modern learning environments use these elements as cornerstones in the deve lopment work.

\section{References}

Albright, M. (1999). Teaching in the information age: A new look. In Theall, M. (Ed.) New Directions for Teaching and Learning. San Francisco: Jossey-Bass Publications, 91-98.

Bailey, D., Brown, J., \& Kelly, P. (1997). Academic advice, personal counseling and on-programme guidance in the Open University. In Personal Tutoring and Advice in Focus, Higher Education Quality Council, London.

Conway, M., \& Kahney, H. (1987). Transfer of learning in inference problems. John Wiley, Chichester.

Jonassen, D.H. (2000). Computers as mindtools for schools: Engaging critical thinking. Upper Saddle River, NJ: Merrill/Prentice Hall.

Jonassen, D.H., Peck, K.C., \& Wilson, B.G. (1999). Learning with technology: A constructivist perspective. Upper Saddle River, NJ: Merrill/Prentice Hall.

Jonassen, D.H., Reeves, T., Hong, N., Harvey, D., \& Peters, K. (1997). Concept mapping as cognitive learning and asses sment tools . Journal of Interactive Learning Research, 8(3), 289-308.

Raskin, J. (2000). The human interface: New directions for designing interactive systems. Addison-Wesley Longman Inc, Massachusetts. 
Reeves, T.C., \& Laffey, J. (1999). Design, assessment, and evaluation of a problem-based learning environment in undergraduate engineering. Higher Education Research \& Development, 18(2), 219-232.

Rowntree, D. (1992). Exploring open and distance learning. Kogan Page, London.

Scott, P., \& Phillips, M. (1998). Developing Web-based student support systems: telling student stories on the Internet. In Eisenstadt, M., \& Vincent, T. The Knowledge Web: Learning and Collaborating on the Net. Kogan Page, London.

Sumner, T., \& Taylor, J. (1998). Media integration through meta-learning environments. In Eisenstadt, M., \& Vincent, T. The Knowledge Web: Learning and Collaborating on the Net. Kogan Page, London.

Taylor, J., Sumner, T., \& Law, A. (1997). Talking about multimedia : A layered design framework. The Journal of Educational Media, 23(2-3), 215-141.

Tella, S., Vahtivuori, S., Vuorento, A., Wager, P., \& Oksanen, U. (2001). Verkko opetuksessa-opettaja verkossa. [The Net in Teaching - The Teacher on the Net]. Edita, Helsinki.

Vivet, M. (1996). The classroom as one learning environment of the future. Journal of Universal Computer Science, 2.

Wild, M., \& Quinn, C. (1998). Implications of educational theory for the design of instructional multimedia.British Journal of Educational Technology, 29(1), 73-82.

\section{Biography}

Dr. Seppo Sirkemaa works with Turku School of Economics and Business Administration, Pori unit. His research interests include information technology infrastructure, network management and the role of information technology in education. The writer works also as an IT consultant at sirkemaa.com 